Pesq. Vet. Bras. 37(11):1331-1335, novembro 2017 DOI: $10.1590 / \mathrm{S} 0100-736 \mathrm{X} 2017001100022$

\title{
Proventricular dilatation disease (PDD) outbreak in blue-and-gold macaws (Ara ararauna) in the State of Santa Catarina, southern Brazil ${ }^{1}$
}

\author{
Jeann Leal de Araujo ${ }^{2}$, Thierry Grima de Cristo ${ }^{3,4}$, Raissa Moreira de Morais ${ }^{3,4}$, \\ Leonardo Silva da Costa ${ }^{3}$, Giovana Biezus ${ }^{4,5}$, Thiago Rinaldi Müller ${ }^{5}$, Raquel \\ Rubia Rech ${ }^{2}$ and Renata Assis Casagrande ${ }^{3,4 *}$
}

\begin{abstract}
Araujo J.L., Cristo T.G., Morais R.M., Costa L.S., Biezus G., Müller T.R., Rech R.R. \& Casagrande R.A. 2017. Proventricular dilatation disease (PDD) outbreak in blue-andgold macaws (Ara ararauna) in the State of Santa Catarina, southern Brazil. Pesquisa Veterinária Brasileira 37(11):1331-1335. Laboratório de Patologia Animal, Centro de Ciências Agroveterinárias, Universidade do Estado de Santa Catarina, Av. Luís de Camões, 2090, Conta Dinheiro, Lages, SC 88520-000, Brazil. E-mail: renata.casagrande@udesc.br

Proventricular dilatation disease (PDD) is a lethal and important disease of captive psittacine birds, and affects a wide range of species, including endangered ones, and lacks an effective treatment. This report describes PDD in three blue-and-gold macaws (Ara ararauna) in southern Brazil. All three macaws originated from the same aviary and presented similar clinical signs including anorexia, apathy, emaciation and prostration. At necropsy, one of the macaws presented an enlarged proventriculus. Histologically, lymphoplasmacytic infiltrates was observed in the ganglia and nerves of the esophagus, crop, proventriculus, ventriculus, heart, adrenal glands, and adrenal medulla of all three cases. Two macaws had meningoencephalomyelitis and one had myocarditis. Immunohistochemistry identified PaBV antigen in the brain, proventricular, ventricular ganglia, and epicardial ganglia, and cardiomyocytes of all three macaws.
\end{abstract}

INDEX TERMS: Proventricular dilatation disease, PDD, blue-and-gold macaw, Ara ararauna, ganglioneuritis, meningoencephalomyelitis, psittacine birds, viral diseases.

RESUMO.- [Surto de doença da dilatação proventricular em araras-canindé (Ara ararauna) no estado de Santa Catarina, sul do Brasil.] A doença da dilatação proventricular (PDD) e uma importante e fatal doença de psitacídeos de cativeiro, que afeta uma grande variedade de espécies e não tem um tratamento efetivo até o momento. Este re-

\footnotetext{
${ }^{1}$ Received on April 25, 2017.

Accepted for publication on July 6, 2017.

${ }^{2}$ Department of Veterinary Pathobiology, Texas A\&M University, 400 Raymond Stotzer Parkway, TAMU 4467, College Station, Texas, USA.

${ }^{3}$ Laboratório de Patologia Animal, Centro de Ciências Agroveterinárias, Universidade do Estado de Santa Catarina (UDESC), Av. Luís de Camões 2090, Bairro Conta Dinheiro, Lages, SC 88520-000, Brazil. *Autor para correspondência: renata.casagrande@udesc.br

${ }^{4}$ Programa de Pós-graduação em Ciência Animal, UDESC, Av. Luís de Camões 2090, Bairro Conta Dinheiro, 88520-000, Lages, SC, Brazil.

${ }^{5}$ Hospital de Clínicas Veterinárias, Centro de Ciências Agroveterinárias, UDESC, Av. Luís de Camões 2090, Bairro Conta Dinheiro, Lages, SC 88520-000, Brazil.
}

lato descreve PDD em três araras canindé (Ara ararauna) no sul do Brasil. Todas as três araras eram provenientes do mesmo criatório e apresentaram sinais clínicos semelhantes incluindo anorexia, apatia, emaciação e prostração. $\mathrm{Na}$ necropsia, uma das araras apresentou proventrículo dilatado. No exame histopatológico, infiltrados linfoplasmacitários foram observados em gânglios e nervos do esôfago, inglúvio, proventrículo, moela, coração, glândulas adrenais e rins de todos os casos. Adicionalmente, meningoencefalomielite foi observada em duas araras e miocardite em uma. A imuno-histoquímica identificou antígenos de PaBV no encéfalo, coração, proventrículo e moela de todos os casos.

TERMOS DE INDEXAÇÃO: Doença da dilatação proventricular, arara-canindé, Ara ararauna, ganglioneurite, meningoencefalomielite, psitacídeos, doenças virais.

\section{INTRODUCTION}

Proventricular dilatation disease (PDD) is a lethal and important disease of captive psittacine birds, affects a wide 
range of species, including several endangered species,and lacks an effective treatment (Staeheli et al. 2010, Wyss et al. 2009). PDD has been identified worldwide, in North America, Europe, Asia, Africa (Hoppes et al. 2010), and South America, including Brazil (Donatti et al. 2014, Encinas-Nagel et al. 2014, Philadelpho et al. 2014).

PDD is caused by Psittaciform 1 bornavirus (PaBV), a non-segment single stranded, negative sense virus of the order Mononegavirales (Honkavuori et al. 2008, Kistler et al. 2008). PaBV has been described in more than 80 species of psittacine birds (Payne et al. 2011). Avian bornaviruses were recently rearranged in 5 main species: Psittaciform 1 bornavirus (PaBV-1, 2, 3, 4 and 7); Psittaciform 2 bornavirus (PaBV-5); Passeriform 1 bornavirus (CnBV-1, 2, and 3); Passeriform 2 bornavirus (EsBV-1) and Waterbird 1 bornavirus (ABBV-1 and 2). PaBV- 6 and 8 remain as tentative/ unclassified bornaviruses (Afonso et al. 2016).

$\mathrm{PaBV}$ is a neurotropic virus and, microscopically, PDD is usually characterized by lymphoplasmacytic encephalomyelitis and ganglioneuritis. The latter is especially prominent in the enteric nervous system, but also commonly seen in adrenal glands and heart. Macroscopically, the dilatation of the proventriculus is the most striking lesion of PDD, which can lead in extreme cases to proventricular wall rupture and coelomitis (Araujo et al. 2016).

PDD can be manifested as gastrointestinal (regurgitation, undigested seeds in the feces, and emaciation) and/or neurological (lethargy, ataxia, depression, and coma) clinical signs. PDD may occur as solitary cases or outbreaks, but usually culminates in death (Kistler et al. 2010, Ogawa et al. 2011, Piepenbring et al. 2012). This report describes three cases of PDD in blue-and-gold macaws (Ara ararauna) originated from a private facility in Southern Brazil.

\section{MATERIALS AND METHODS}

Epidemiological and clinical findings. All three macaws were kept in captivity for more than 10 years in a single enclosure at a psittacine aviary in the State of Santa Catarina, Southern Brazil. This conservation facility had a total of 26 blue-and-gold macaws with other psittacine birds, including parakeets and amazon parrots. No history of recent bird introduction was reported. Two cases occurred in July 2016 and one case in August 2016. Clinical findings were reported by the owner in macaws $1 \& 2$ and also by clinicians who examined macaw 3 . Radiographs were available from macaw 3.

Necropsy and sample collection. Necropsy was performed in macaws 1 and 3. Samples from brain, spinal cord, brachial plexus, sciatic nerve, skin, eye, head sinuses, skeletal muscle, bone marrow, thyroid and parathyroid glands, trachea, lungs, air sacs, heart, liver, spleen, kidneys, adrenal glands, esophagus, crop, proventriculus, ventriculus, pancreas, and intestines were collected. Additionally, the breeder performed sample collection of case 2 and submitted samples from ventriculus, liver, heart, lungs and spleen from for histopathological examination. All samples were fixed in $10 \%$ neutral buffered formalin.

Histopathology and immunohistochemistry. Fixed samples were processed routinely for histologic evaluation and examined by light microscopy. Immunohistochemistry (IHC) was done on an automated stain equipment using a polyclonal antibody targeting a specific region of the PaBV N-protein. Due to the intranuclear replication nature of $\mathrm{PaBV}$, only cells with intranuclear or intra- nuclear and intracytoplasmic immunolabeling were considered positive. IHC was performed on samples from ventriculus, heart, brain, and/or spinal cord from all three birds.

\section{RESULTS}

Clinical findings. Macaws 1 and 2 developed clinical signs in July 2016 and were kept isolated. The clinical signs progressed over a one month period to culminate in apathy, anorexia with regurgitation upon gavage feeding, crop stasis, emaciation, prostration and a one week history of pasty stools and undigested seeds in feces. Treatment with vitamin B12 and sulfa-based antibiotics was unsuccessful. The breeder submitted macaw 1 for necropsy and selected samples from macaw 2 for histologic examination. Macaw 3 developed clinical signs suggestive of PDD in August 2016; the patient had a one week history of anorexia requiring gavage feeding. The macaw was referred to the Veterinary Hospital at Universidade do Estado de Santa Catarina (HV-UDESC), and upon presentation, clinical signs included prostration, apathy, ruffled feathers, and cachexia. Radiographic examination revealed the liver was moderately decreased in size, attributed clinically to cachexia. Unfortunately, macaw 3 died during the radiographic procedure.

Necropsy. Macaw 1 was emaciated and the proventriculus was thin-walled and markedly dilated by large amount of ingesta (Fig.1). Macaw 3 did not present a dilated pro-

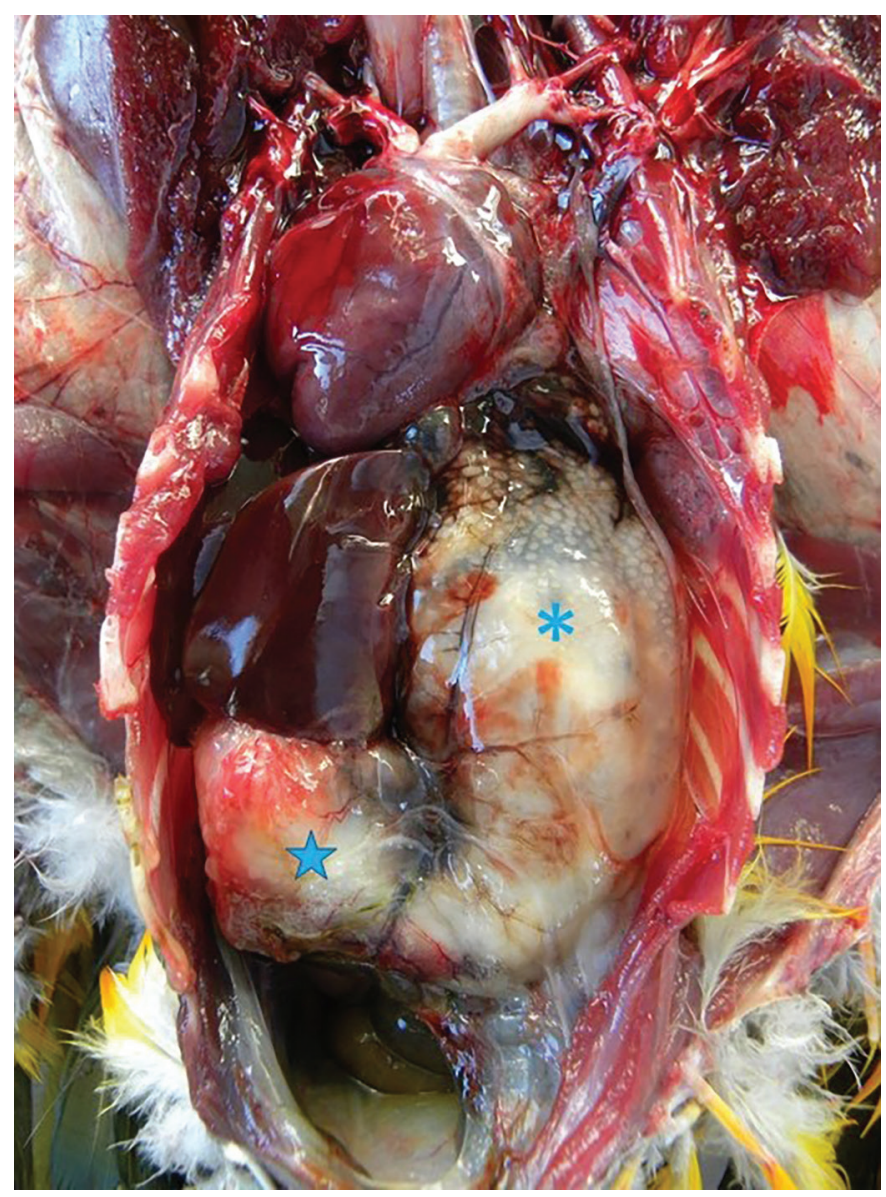

Fig.1. Gross finding. Note the enlarged thin-walled proventriculus (asterisk), disproportional in size to the ventriculus (star). 


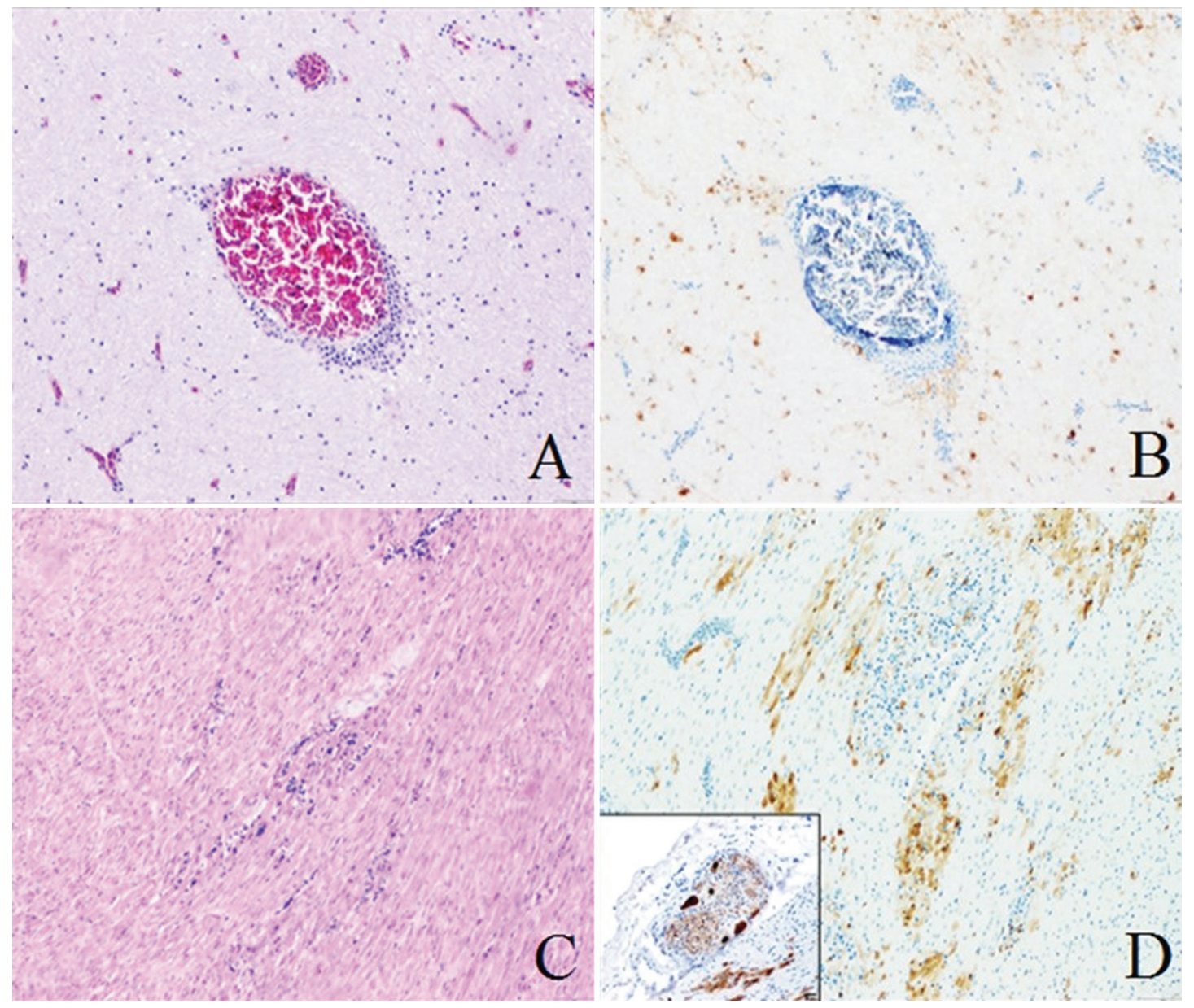

Fig.2. Histological and immunohistochemical findings. (A) Lymphoplasmacytic perivascular cuffing in the cerebrum of macaw 1. (B) Immunohistochemistry confirmed intranuclear PaBV-N protein antigen in glial cells and neurons. (C), Severe multifocal lymphoplasmacytic myocarditis (macaw 3), and (D) immunohistochemistry identified intranuclear and intracytoplasmatic PaBV-N protein antigen in cardiomyocytes and lymphocytes. Additionally, immunolabeling was present in neurons and satellite cells of epicardial ganglia (inset) of macaw 3 .

ventriculus; however, the wall was thin and flaccid. No ingesta was observed in the gastrointestinal tract of macaw 3.

Histopathology and immunohistochemistry. Multifocal, moderate to marked, lymphoplasmacytic infiltrates were within nerves and ganglia of the ventriculus (macaws $1,2,3$ ), esophagus (macaw 1), crop (macaw 1 and 3), and proventriculus (macaw 3 ), as well as in the adrenal medulla (macaws 1 and 3) and adjacent ganglia (macaw 3). Additionally, one to two layers of lymphoplasmacytic and histiocytic infiltrates expanded Virchow-Robin spaces in the cerebrum, cerebellum, spinal cord and the meninges in macaws 1 and 3. Mild infiltrates were in the optic nerve, brachial plexus and sciatic nerve of macaws 1 and 3. Macaw 3 presented a severe myocarditis. Mild epicardial ganglioneuritis was observed in macaws 2 and 3 . Neurons of the ganglia of ventriculus (macaws 1, 2 and 3), cardiomyocytes of heart and epicardial ganglia (macaw 2), and also in neurons of the brain and spinal cord (macaws 1 and 3) were positive for PaBV $\mathrm{N}$ protein immunolabeling (Fig.2).

\section{DISCUSSION}

All three macaws in the present study had typical clinicopathological findings of PDD, which was confirmed by immu- nohistochemical methods (Hoppes et al. 2010). Definitive diagnosis of PDD is usually postmortem and performed by histological identification of lymphoplasmacytic inflammation in the central nervous system (CNS) and mainly in the ganglia and nerves of gastrointestinal tract on target tissues in conjunction with immunohistochemical and/or molecular detection of PaBV (Gray et al. 2010, Araujo et al. 2016; Villanueva et al. 2010). Immunohistochemistry is a useful tool in diagnostic pathology and many infectious agents can be retrieved after several weeks of fixation in formalin (Webster et al. 2010). Therefore, not only brain and spinal cord should be collected during necropsies of PDD-suspected cases, but also visceral organs with abundant ganglia such as proventriculus, ventriculus, crop, heart, intestines, and adrenal glands (Ouyang et al. 2009, Gray et al. 2010, Araujo et al. 2016). Interestingly, macaw 3 presented a severe myocarditis, which is an uncommon lesion of PDD (Vice 1992; Wunschmann et al. 2011), but might explain why this bird died during the radiographic procedure. Antemortem diagnosis of PDD is often inconclusive, because it is usually performed by histological evaluation of crop biopsies and inflammatory infiltrates are not always present in these cases (Gregory et al. 1996, Schmidt et al. 2015). Immuno- 
histochemical analysis of these biopsies in conjunction with histopathological evaluation is an important tool to prevent false negative results, because antigen spread usually precedes the inflammation in PDD cases (Araujo et al. 2016).

Evidence of PaBV-infection, PDD or both have been recently reported in a wide-range of native psittacine birds in Brazil such as blue-and-gold macaws (Ara ararauna), scarlet macaws (Ara macao), blue-winged macaws (Primolius maracana), chestnut-fronted macaws (Ara severa), pileated parrots (Pionopsitta pileata), vinaceous-breasted parrots (Amazona vinacea), scaly-headed parrots (Pionus maximiliani), red-browed Amazon parrots (Amazona rhodocorytha), blue-fronted amazons (Amazona aestiva), white-eyed parakeets (Aratinga leucophtalmus), plain parakeets (Brotogeris tirica), orange-winged amazons (Amazona amazonica), yellow-faced amazons (Amazona xanthops), yellow-chevroned parakeets (Brotogeris chiriri), and golden parakeets (Guarouba guarouba). Fewer exotic species such as Australian ringnecks (Barnadius zonarius), cockatiels (Nymphicus hollandicus), African grey parrots (Psittacus erithacus), and umbrella cockatoos (Cacatua alba) have been reported as positive. These birds were originated from breeding facilities, clinics, or rehabilitation centers from the states of Sao Paulo, Rio de Janeiro, Mato Grosso do Sul and Minas Gerais (Donatti et al. 2014, Encinas-Nagel et al. 2014, Philadelpho et al. 2014). Although one of these studies reported PaBV infection or PDD signs in free-ranging psittacines (Encinas-Nagel et al. 2014), these birds were kept in captivity after rescue or confiscation by environmental authorities, and information about how long these animals were kept in these facilities and their status prior captivity are unclear.

The most common PaBV genotypes reported in PDD cases across the world are PaBV- 2 and PaBV-4 (Rubbenstroth et al. 2016). Two PaBV genotypes have been identified in Brazil so far: PaBV-4, and also a possible novel genotype tentatively named PaBV-8 (Philadelpho et al. 2014), which remains as an unclassified/tentative bornaviruses (Afonso et al. 2016). Unfortunately, we were not able to determine the genotype involved in this case report.

The pathogenesis of PDD is still unclear, and crucial information about PaBV route of infection, target cells and immune response is poorly known. The most accepted theory about PDD pathogenesis states that PaBV spreads throughout the nervous system and directly triggers the inflammatory and immunological changes observed in this disease (Piepenbring et al. 2012). Recently, experimental studies have shown that, nasal and oral routes of infection failed to reproduce disease in psittacine birds (Heckmann et al. 2017); however, after intramuscular inoculation, in the early stages of infection, PaBV spreads centripetally to the CNS after intramuscular inoculation and then centrifugally out of the CNS to peripheral ganglia, with a propensity to affect ganglia in the gastrointestinal tract (Araujo et al. 2017).

PDD must be always considered in cases of proventricular dilatation in psittacine birds; however, gastric impaction, gastric mycobacteriosis, Macrorhabdus ornithogaster infection, fungal proventriculitis and lead toxicosis can also cause proventricular dilatation in psittacine birds and must be considered as differential diagnoses (Rinder et al. 2009, Schmidt et al. 2015). Similarly, PaBV can also cause a primary neurological disease and PDD must be considered as a potential diagnosis, even if no gastrointestinal signs are present. However, other infectious agents, trauma, nutritional deficiency or heavy metal toxicity must be considered as differential diagnoses of neurological disease in psittacine birds.

Treatment options for PDD are limited with a lack of in vivo validated antiviral therapeutics, and the role of anti-inflammatory and immunosuppressive options is controversial (Musser et al. 2015). Single case reports of successful use of anti-inflammatory and immunosuppressive drugs in the treatment of PDD-affected birds should be interpreted carefully, because some of these drugs have been often reported to cause worsening of clinical signs or the clinical trials lack the necessary controls (Hoppes et al. 2013, Lierz 2016). In this report, treatment was limited to supportive care and isolation of the affected birds.

Although PDD/PaBV infection has been previously reported in blue-and-gold macaws in Brazil, to the author's knowledge this is the first report of PDD in psittacine birds in captivity in southern Brazil. This study reaffirms the wide geographic distribution of $\mathrm{PaBV}$ and highlights the importance of the histopathology and also of immunohistochemistry as an ancillary test for confirmation of the disease.

\section{REFERENCES}

Afonso C.L., Amarasinghe G.K., Banyai K., Bao Y., Basler C.F., Bavari S., Bejerman N., Blasdell K.R., Briand F.X., Briese T., Bukreyev A., Calisher C.H., Chandran K., Cheng J., Clawson A.N., Collins P.L., Dietzgen R.G., Dolnik O., Domier L.L., Durrwald R., Dye J.M., Easton A.J., Ebihara H., Farkas S.L., Freitas-Astua J., Formenty P., Fouchier R.A., Fu Y., Ghedin E., Goodin M.M., Hewson R., Horie M., Hyndman T.H., Jiang D., Kitajima E.W., Kobinger G.P., Kondo H., Kurath G., Lamb R.A., Lenardon S., Leroy E.M., Li C.X., Lin X.D., Liu L., Longdon B., Marton S., Maisner A., Muhlberger E., Netesov S.V., Nowotny N., Patterson J.L., Payne S.L., Paweska J.T., Randall R.E., Rima B.K., Rota P., Rubbenstroth D., Schwemmle M., Shi M., Smither S.J., Stenglein M.D., Stone D.M., Takada A., Terregino C., Tesh R.B., Tian J.H., Tomonaga K., Tordo N., Towner J.S., Vasilakis N., Verbeek M., Volchkov V.E., Wahl-Jensen V., Walsh J.A., Walker P.J., Wang D., Wang L.F., Wetzel T., Whitfield A.E., Xie J.T., Yuen K.Y., Zhang Y.Z. \& Kuhn J.H. 2016. Taxonomy of the Order Mononegavirales. Arch. Virol. 161:2351-2360.

Araujo J.L., Rech R.R., Heatley J.J., Guo J., Giaretta P.R., Tizard I. \& Hoffmann A.R. 2017. From nerves to brain to gastrointestinal tract: A timebased study of parrot bornavirus 2 (PaBV-2) pathogenesis in cockatiels (Nymphicus hollandicus). PLoS One. 12:1-16.

Araujo J.L., Plumlee Q., Rech R.R., Winkel-Blair A., Hoppes S. \& Schneider S.M. 2016. Proventricular Rupture Associated with Psittaciforme 1 Bornavirus (PaBV) Infection in a Major Mitchell Cockatoo (Lophochroa leadbeateri). Braz. J. Vet. Pathol. 9:83-87.

Donatti R.V., Resende M., Ferreira F.C.J., Marques M.V.R., Ecco R., Shivaprasad H.L., Resende J.S. \& Martins N.R. 2014. Fatal proventricular dilatation disease in captive native psittacines in Brazil. Avian Dis. 58:187-93.

Encinas-Nagel N., Enderlein D., Piepenbring A., Herden C., Heffels-Redmann U., Felippe P.A.N., Arns C., Hafez H.M. \& Lierz M. 2014. Avian Bornavirus in Free-Ranging Psittacine Birds, Brazil. Emerg. Infect. Dis. 20:2103-2106.

Gray P., Hoppes S., Suchodolski P., Mirhosseini N., Payne S., Villanueva I., Shivaprasad H.L., Honkavuori K.S., Lipkin W.I., Briese T., Reddy S.M. \& Tizard I. 2010. Use of avian bornavirus isolates to induce proventricular dilatation disease in conures. Emerg. Infect. Dis. 16:473-479. 
Gregory C.R., Latimer K.S., Campagnoli R.P. \& Ritchie B.W. 1996. histologic evaluation of the crop for diagnosis of proventricular dilatation syndrome in psittacine birds. J. Vet. Diagn. Invest. 8:76-80.

Heckmann J., Enderlein D., Piepenbring A.K., Herzog S., Heffels-Redmann U., Malberg S., Herden C. \& Lierz M. 2017. Investigation of different infection routes of parrot bornavirus in cockatiels. Avian Dis. 61:90-95.

Honkavuori K.S., Shivaprasad H.L., Williams B.L., Quan P.L., Hornig M., Street C., Palacios G., Hutchison SK., Franca M., Egholm M., Briese T. \& Lipkin W.I. 2008. Novel borna virus in psittacine birds with proventricular dilatation disease. Emerg. Infect. Dis. 14:1883-1886.

Hoppes S., Gray P.L., Payne S., Shivaprasad H.L. \& Tizard I. 2010. The isolation, pathogenesis, diagnosis, transmission, and control of avian bornavirus and proventricular dilatation disease. Vet. Clin. N. Am., Exot. Anim. Pract. 13:495-508.

Hoppes S., Heatley J.J., Guo J., Turner D., Shivaprasad H.L. \& Tizard I. 2013. Meloxicam treatment in cockatiels (Nymphicus hollandicus) infected with avian bornavirus. J. Exot. Pet Med. 22:275-279.

Kistler A.L., Gancz A., Clubb S., Skewes-Cox P., Fischer K., Sorber K., Chiu C.Y., Lublin A., Mechani S., Farnoushi Y., Greninger A., Wenn C.C., Karlene S.B., Ganem D. \& DeRisi J.L. 2008. Recovery of divergent avian bornaviruses from cases of proventricular dilatation disease: identification of a candidate etiologic agent. Virology 5:88.

Kistler A.L., Smith J.M., Greninger A.L., Derisi J.L. \& Ganem D. 2010. Analysis of naturally occurring avian bornavirus infection and transmission during an outbreak of proventricular dilatation disease among captive psittacine birds. J. Virol. 84:2176-2179.

Lierz M. 2016. Avian bornavirus and proventricular dilation disease, p.2846. In: Speer B. (Ed.), Current Therapy in Avian Medicine and Surgery. Elsevier, St Louis.

Musser J.M.B., Heatley J.J., Koinis A.V., Suchodolski P.F., Guo J., Escandon P. \& Tizard I. 2015. Ribavirin inhibits parrot bornavirus 4 replication in cell culture. PLoS One 10:e0134080.

Ogawa H., Sanada Y., Sanada N., Kudo M., Tuchiya K., Kodama T. \& Uetsuka K. 2011. Proventricular dilatation disease associated with avian bornavirus infection in a Citron-crested Cockatoo that was born and handreared in Japan. J. Vet. Med. Sci. 73:837-840.

Ouyang N., Storts R., Tian Y., Wigle W., Villanueva I., Mirhosseini N., Payne S., Gray P. \& Tizard I. 2009. Histopathology and the detection of avian bornavirus in the nervous system of birds diagnosed with proventricular dilatation disease. Avian Pathol. 38:393-401.

Payne S., Shivaprasad H.L., Mirhosseini N., Gray P., Hoppes S., Weissenbock
H. \& Tizard I. 2011. Unusual and severe lesions of proventricular dilatation disease in cockatiels (Nymphicus hollandicus) acting as healthy carriers of avian bornavirus (ABV) and subsequently infected with a virulent strain of ABV. Avian Pathol. 40:15-22.

Philadelpho N.A., Rubbenstroth D., Guimaraes M.B. \& Piantino Ferreira A.J. 2014. Survey of bornaviruses in pet psittacines in Brazil reveals a novel parrot bornavirus. Vet. Microbiol. 174:584-590.

Piepenbring A.K., Enderlein D., Herzog S., Kaleta E.F., Heffels-Redmann U., Ressmeyer S., Herden C. \& Lierz M. 2012. Pathogenesis of avian bornavirus in experimentally infected cockatiels. Emerg. Infect. Dis. 18:234241.

Rinder M., Ackermann A., Kempf H., Kaspers B., Korbel R. \& Staeheli P. 2009. Broad tissue and cell tropism of avian bornavirus in parrots with proventricular dilatation disease. J. Virol. 83:5401-7.

Rubbenstroth D., Schmidt V., Rinder M., Legler M., Twietmeyer S., Schwemmer P. \& Corman V.M. 2016. Phylogenetic analysis supports horizontal transmission as a driving force of the spread of avian bornaviruses. PLoS One 11:e0160936.

Schmidt R.E., Reavill D.R. \& Phalen D.N. 2015. Gastrointestinal system and pancreas, p.55-94. In: Schmidt R.E., Reavill D.R. \& Phalen D.N. (Eds), Pathology of Pet and Aviary Birds. 2nd ed. Wiley, Hoboken.

Staeheli P., Rinder M. \& Kaspers B. 2010. Avian bornavirus associated with fatal disease in psittacine birds. J. Virol. 84:6269-6275.

Vice C.A. 1992. Myocarditis as a component of psittacine proventricular dilatation syndrome in a Patagonian conure. Avian Dis. 36:1117-1119.

Villanueva I., Gray P., Mirhosseini N., Payne S., Hoppes S., Honkavuori K.S., Briese T., Turner D. \& Tizard I. 2010. The diagnosis of proventricular dilatation disease: use of a western blot assay to detect antibodies against avian borna virus. Vet. Microbiol. 143:196-201.

Webster J.D., Miller M.A., DuSold D. \& Ramos-Vara J. 2010. Effects of prolonged formalin fixation on the immunohistochemical detection of infectious agents in formalin-fixed, paraffin-embedded tissues. Vet. Pathol. 47:529-535.

Wunschmann A., Honkavuori K., Briese T., Lipkin W.I., Shivers J. \& Armien A.G. 2011. Antigen tissue distribution of avian bornavirus (ABV) in psittacine birds with natural spontaneous proventricular dilatation disease and ABV genotype 1 infection. J. Vet. Diagn. Invest. 23:716-726.

Wyss S., Deb A., Watson R. \& Hammer S. 2009. Radiographic measurements for PDD diagnosis in spix's macaws (Cyanopsitta spixii) at $\mathrm{Al}$ Wabra Wildlife Preservation (AWWP), Quartar. Proc. International Conference on Diseases of Zoo and Wild Animals, University of Zürich, p.349-354. 